Research Article

\title{
Visceral Adipose Tissue was Associated with Increased Risk of Insulin Resistance in Lean Polycystic Ovarian Syndrome, Independent with Retinol Binding Protein-4
}

\section{Jaringan Adiposa Viseral berkaitan dengan Peningkatan Risiko Resistensi Insulin pada Sindrom Ovarium Polikistik dengan Indeks Massa Tubuh Normal, Independen terhadap Retinol Binding Protein-4}

\author{
Vita Silvana, Andon Hestiantoro, Muharam Natadisastra, Kanadi Sumapraja, Budi Wiweko
}

\author{
Division of Reproductive Immunoendocrinology \\ Department of Obstetrics and Gynecology \\ Faculty of Medicine Universitas Indonesia, \\ Dr. Cipto Mangunkusumo Hospital
}

Jakarta

\begin{abstract}
Objective: To determine whether visceral adipose tissue or serum RBP-4 were related to the risk increment of insulin resistance in normal BMI PCOS patients.

Methods: This was a cross-sectional study conducted in normal body mass index PCOS patients at Yasmin Clinic, RSCM, Jakarta from July 2014 until March 2015. Diagnosis of PCOS was established using Rotterrdam (2003) criteria. Insulin resistance was confirmed by using ratio of HOMA-IR $>1.4$.
\end{abstract}

Results: Among 40 subjects, 20 subjects (50\%) belong insulin resistance group. Serum RBP-4 level was higher in the insulin-resistant group $(p=0.06)$. After ROC analysis was conducted, the area under curve for serum RBP-4 was $69.9 \%$ (CI 95\% -3754.77 - (186.60-7696.14, p=0.061)). The cut-off level of serum RBP-4 was $23814.5 \mathrm{ng} / \mathrm{mL}$ yielded sensitivity and specificity to a level of $60 \%$ and $60 \%$, respectively. After logistic regression was analyzed, visceral adipose tissue demonstrated substantial association with the risk increment of insulin resistance in normal BMI PCOS patients.

Conclusions: Visceral adipose tissue demonstrated substantial association with the risk increment of insulin resistance in normal BMI PCOS patients, independent with serum RBP-4 levels.

Keywords: body mass index, diagnosis, insulin resistance, PCOS, retinol-binding protein-4.

\begin{abstract}
Abstrak
Tujuan: Untuk menentukan apakah jaringan adiposa viseral atau serum RBP-4 berhubungan dengan peningkatan risiko resistensi insulin pada Sindrom Ovarium Polikistik dengan indeks masa tubuh normal.
\end{abstract}

Metode: Studi potong lintang dilakukan pada subjek SOPK dengan IMT normal di Klinik Yasmin, RSCM, Jakarta sejak Juli 2014 sampai dengan Maret 2015. Penegakan diagnosis SOPK dilakukan dengan kriteria Rotterdam (2003). Resistensi insulin dikonfirmasi dengan pemeriksaan rasio HOMA-IR > 1.4

Hasil: Diantara 40 subjek, sebanyak 20 subjek (50\%) mengalami resistensi insulin. Kadar serum RBP-4 lebih tinggi pada kelompok resistensi insulin $(p=0.06)$. Setelah dilakukan analisis Receiver Operating Curve (ROC), serum RBP-4 memiliki Area Under the Curve (AUC) sebesar 69.9\% (IK 95\% -3754.77 - (186.60-7696.14, $p=0,061)$ ). Titik potong kadar serum RBP-4 adalah $23814.5 \mathrm{ng} / \mathrm{mL}$ dengan sensitivitas dan spesifisitas masing-masing 60\% dan 60\%. Setelah dilakukan analisis regresi logistik, jaringan adiposa viseral menunjukan asosiasi yang kuat dengan terjadinya resistensi insulin pada pasien SOPK dengan IMT normal.

Kesimpulan: Jaringan adiposa viseral menunjukan asosiasi yang kuat dengan terjadinya resistensi insulin pada SOPK dengan IMT normal, independen terhadap kadar serum RBP-4.

Kata kunci: diagnosis, indeks masa tubuh, resistensi insulin, retinol binding protein-4, SOPK. 


\section{INTRODUCTION}

Polycystic Ovarian Syndrome is a frequent endocrine disorder in women on their reproductive period, affecting $4-18 \%$ of these population using Rotterdam criteria.1 Insulin resistance, hyperandrogenism, and gonadotropin axis disorder were considered to be a key for PCOS pathophysiology. Insulin resistance is also attributed to the development of later complications, e.g. metabolic syndrome, type-2 diabetes mellitus, and cardiovascular disease $\mathrm{e}^{2,3}$

Fat also contributes to the pathophysiology of PCOS. It is also supported by other studies that most of the PCOS patient had excess body fat level, even though several patients still had normal body fat level based on BMI calculation. ${ }^{4,5}$ An excess fat tissue can be an etiologic factor in the pathogenesis of low-grade chronic inflammation in PCOS. ${ }^{6}$ The hypertrophied accumulated fat tissue can cause decreased blood perfusion and end up with fat tissue hypoxia. Apoptosis process may follow the fat hypoxia that causes a higher macrophage cell infiltration and enhance the secretion of proinflammatory cytokines from adipose tissue.

Low-grade chronic inflammation can be expressed if there is an enhancement in cytokines productions such as CRP, TNFa, procalcitonin and interleukin-6, associated with the body's immune response mechanism. TNFa and IL- 6 as pro-inflammatory cytokines can induce phosphorylation of serine residues on insulin receptor substrate-1, which can lead to insulin resistance. $^{7}$

Several factors can be used in PCOS patient in determining body fat levels such as body mass index, waist to hip ratio and waist circumference, but for those patient who had normal or underweight posture, those measurement will be within normal limit. Whereas from the previous studies reported that insulin resistance may also be found either in obese or in non-obese PCOS patients. Among those with non-obese PCOS patients showing waist circumference less than $80 \mathrm{~cm}$, the prevalence of insulin resistance was observed in $30-50 \%$ of population. In addition, using CT scan, normal BMI PCOS patients showed a significantly higher percentage of visceral adipose tissue. ${ }^{8-10}$
Visceral adipose tissue plays a central role in pathophysiology related to PCOS compared to subcutaneous adipose tissue. A previous study on a mouse model for PCOS showed structural changes in adipose tissue that play an important role in the pathophysiology of insulin resistance in PCOS. CT scan and MRI were considered gold standards for adipose tissue estimation.,11-12 Visceral adipose tissue secretes adipocytokines and adiponectin which are related to insulin resistance. Adipocytokines produces several hormones, one of them is retinol-binding protein 4 (RBP-4). ${ }^{13-16}$ RBP-4 might be a suitable marker that signals the presence of early insulin resistance and may contribute to the pathophysiology of insulin resistance, by affecting hepatic gluconeogenesis and disturbing the mechanism of the insulin signalling system in muscles and also halts glucose uptake. Besides, RBP-4 is a gender specific marker that higher in women. RBP-4 level is raised before diabetes occurred. $8,10,16-20$

Previous studies found conflicting results regarding the association of RBP-4 serum level with insulin resistance among PCOS patients. 3,15,19,21 Interestingly, another studies found a significant positive correlation of RBP4 level and visceral adipose tissue percentage measured by CT scan or MRI. ${ }^{13,22-24}$ Thus, this research is purposed to know the accuracy and cut-off point of RBP-4 level among our patients to decide whether serum RBP-4 might be a suitable marker for insulin resisance among PCOS patients with normal body mass index.

\section{METHODS}

This was a cross-sectional study conducted at Yasmin Clinic, RSCM, Jakarta from July 2014 until March 2015. Subjects were recruited consecutively. The inclusion criteria applied in this study were patients aged 18-40 years old following Rotterdam 2003 citeria for PCOS diagnosis. PCOS is considered when two or more criteria fulfilled (oligo/anovulation, hyperandrogenism, and appearance of polycystic ovarian based on ultrasonography), and body mass index 18.5$24.9 \mathrm{Kg} / \mathrm{m}^{2}$. Patients with infertility from patients' history, hyperprolactinemia, confirmed type2 diabetes mellitus, and already in ovulation induction agents, previous glucocorticoid medication, oral hypoglycemic agents, and insulin during the last three months at the time of data collection were excluded. 
We measured the body mass index and waist circumference. Ten $\mathrm{ml}$ blood samples from fossa cubity vein were collected for fasting plasma glucose, fasting insulin level, and serum RBP4 level measurements. Laboratory tests were conducted at Prodia ${ }^{\circledR}$ laboratory, Jakarta. RBP4 level was determined using ELISA method (Quantikine Human RBP4 Immunoassay). Insulin resistance is determined by HOMA-IR $>1.4$ based on a previous study of the Chinese population. 25,26

All numerical data were tested for its normality using the Shapiro-Wilk test. Normally distributed data presented as mean \pm standard deviation, otherwise, the data were presented as median (minimum-maximum). For diagnostic analysis, we determined the cut-off point of RBP-4 using statistical analysis for the best possible sensitivity and specificity. Categorical and numerical data bivariate analysis among insulin resistance and non-insulin resistance were performed using chisquare test and independent t-test, respectively. Variables with initial $p$-value $<0.25$ were included in multivariate analysis using logistic regression with backward LR method to eliminate insignificant variables. ROC was applied to estimate the area under the curve (AUC). P-value $<0.05$ was considered significant. We performed statistical analysis using SPSS (statistical package for Social Science, Chicago, Inc) for windows version 20 .

All subjects had signed informed consent form before included in this study. The study protocol was approved by ethical committee Faculty of Medicine, Universitas Indonesia, Jakarta, Indonesia (form No. 498/H2.F1/ ETIK/2014).

\section{RESULTS}

A total of 40 subjects were recruited during this study period. 20 subjects (50\%) were confirmed having insulin resistance. The mean age of subjects was $27,43 \pm 4,13$ years old with mean body mass index was $22.02 \pm 1.81 \mathrm{~kg} / \mathrm{m}^{2}$. Characteristics of subjects were presented in table 1. Insulin resistance subjects were significantly older, had higher BMI, waist circumference, RBP4 level and percentage of visceral adipose tissue. Among subjects with insulin resistance, RBP4 level was higher than non-insulin resistance group $(26862.93 \pm 6728.69 \mathrm{ng} / \mathrm{ml}$ and 23108.16 $\pm 3630.43 \mathrm{ng} / \mathrm{ml}, \mathrm{p}=0.061)$. The area under the curve for RBP-4 measurement was 0.669. Using $23814.5 \mathrm{ng} / \mathrm{mL}$ as a cut-off point, RBP-4 level had $60 \%$ sensitivity and $60 \%$ specificity.

Table 1. Characteristics of Subjects

\begin{tabular}{|c|c|c|c|c|c|}
\hline Characteristics & $\begin{array}{l}\text { All subjects } \\
N=40(\%)\end{array}$ & $\begin{array}{l}\text { Insulin resistance } \\
\qquad N=20 \text { (\%) }\end{array}$ & $\begin{array}{c}\text { Non-insulin } \\
\text { resistance } \\
\mathbf{N}=20(\%)\end{array}$ & $\begin{array}{l}\text { Mean difference } \\
(95 \% \mathrm{CI})\end{array}$ & P-value \\
\hline Age (years) & $27,43 \pm 4,13$ & $29.27 \pm 3.69$ & $26.32 \pm 4.04$ & $-2.95-(0.36-5.54)$ & 0.03 \\
\hline $\mathrm{BMI}(\mathrm{Kg} / \mathrm{m} 2)$ & $22.02 \pm 1.81$ & $23.02 \pm 1.56$ & $21.43 \pm 1.71$ & $-1.59-(.45-2.68)$ & 0.006 \\
\hline $\begin{array}{l}\text { Waist } \\
\text { circumference }(\mathrm{cm})\end{array}$ & $79.6 \pm 6.66$ & $82.4 \pm 5.60$ & $77.92 \pm 6.57$ & $-4.48-(.269-8.69)$ & 0.038 \\
\hline RBP-4 (ng/ml) & $23867.5(19013-42623)$ & $26862.93 \pm 6728.69$ & $23108.16 \pm 3630.43$ & $-3754.77-(186.60-7696.14)$ & 0.061 \\
\hline \multicolumn{6}{|c|}{ - } \\
\hline Normal & $23(57.5)$ & $10(43.48)$ & $13(56.52)$ & & 0.934 \\
\hline Excessive & $17(42.5)$ & $10(58.82)$ & 7 (41.18) & & \\
\hline \multicolumn{6}{|l|}{$\begin{array}{l}\text { Visceral adipose } \\
\text { tissue }\end{array}$} \\
\hline Normal & $32(80.0)$ & $12(37.5)$ & $20(62.5)$ & & \\
\hline Excessive & $8(20.0)$ & $8(100)$ & $0(0)$ & & $<0.001$ \\
\hline
\end{tabular}

Age, waist circumference, BMI, and visceral adipose tissue were then included in multivariate analysis. Only age and visceral adipose tissue suited to the final multivariate model (Table 2). The risk of insulin resistance were evaluated with ROC curve with AUC 0.669 (CI 95\%; 0.487 0.852 , P-value 0.076) while visceral adipose tissue demonstrated higher AUC level 0.89 (Ci 95\%; 0.647 - 0.956, P-value: 0.002, figure 1 ). 


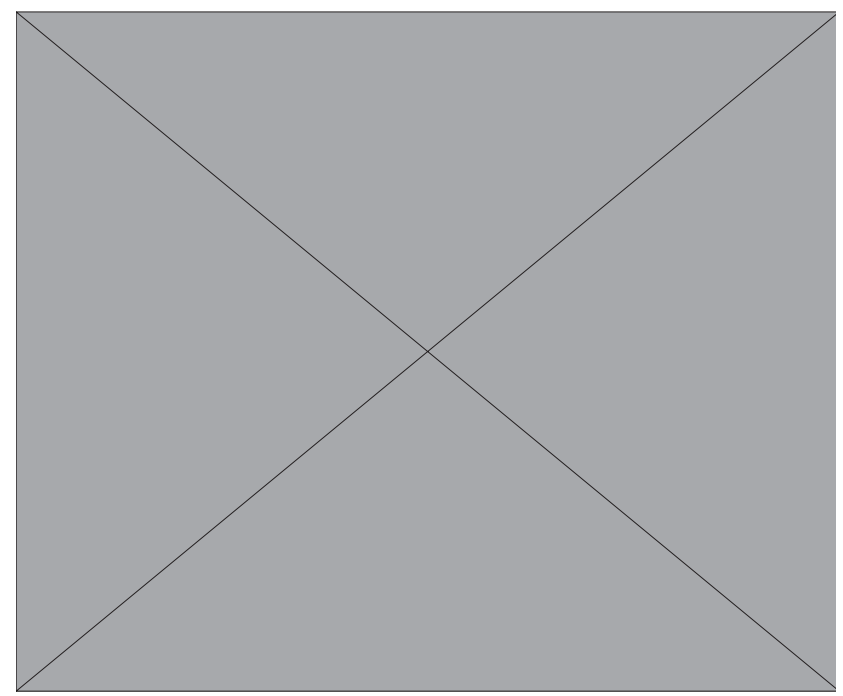

This figure showed ROC between RBP-4 and Visceral adipose tissue with the incidence of insulin resistance in lean PCOS, with AUC

Figure 1. Receiver operating curve of RBP-4 level, Visceral adipose and Insulin Resistance

Table 2. Multivariate Analysis to Calculate the Risk of Insulin Resistance

\begin{tabular}{lcccccccc}
\hline Variables & B & S.E. & Wald & df & P-value & Exp (B) & \multicolumn{2}{c}{ 95\% CI } \\
\hline Age & 0.224 & 0.113 & 3.936 & 1 & 0.047 & 1.252 & 1.003 & 1.562 \\
Visceral & 0.392 & 0.133 & 8.674 & 1 & 0.003 & 1.479 & 1.14 & 1.92 \\
adipose tissue & & & & & & & & \\
Constant & -9.434 & 3.588 & 6.914 & 1 & 0.009 & 0 & & \\
\hline
\end{tabular}

\section{DISCUSSION}

We confirmed 20 out of 40 PCOS patients with normal body mass index (50\%) were insulin resistance. This finding was in agreement with previous studies. They observed that $25 \%$ of PCOS patients belonged to normal body mass index and about a half of them had insulin resistance. In addition, $30-50 \%$ PCOS patient with waist circumference less than $80 \mathrm{~cm}$ were insulin resistance. $8,9,27,28$ The mean level of RBP-4 in this study was $23867.5 \mathrm{ng} / \mathrm{mL}$. Insulin resistance group showed a higher level of RBP-4 compared to the non-insulin resistance group, similar to previous studies. ${ }^{8,15,29}$

Insulin resistance was considered important pathophysiology of PCOS. It was estimated that half of the PCOS patients had impaired insulin signalling in the target tissues. The mechanism of insulin resistance was described, which observed a down-regulation of glucose transport in inuslin signaling process and decline in serine autophosphorilase in insulin receptors. ${ }^{30,31}$ Identified among pregnant women, RBP-4 level $\geq 42 \mathrm{ng} / \mathrm{ml}$ could predict gestasional diabetes mellitus with $75.8 \%$ sensitivity and $63.5 \%$ specificity. Found that RBP-4 level could estimate metabolic syndrome. However, its accuracy for metabolic syndrome among PCOS patients was only $66 \%$.[15] In our study, 23814.5 $\mathrm{ng} / \mathrm{mL}$ as a cut-off point of RBP-4 had moderate level of sensitivity and specificity as a marker for insulin resistance $(60 \%$ sensitivity and $60 \%$ specificity)..$^{14,22,23}$

Our study found that RBP-4 levels in lean PCOS patients did not show any association with insulin resistance, this result was similar with previous study, showed higher RBP-4 levels in subjects with metabolic syndrome, obesity and impaired glucose metabolism. 3,19,21,32,33

Known that RBP-4 synthesis not only in visceral adipose tissue but also in all adipose tissue and mostly in the hepatic tissue, it can be the cause no association between RBP-4 and insulin resistance in normal BMI PCOS patient. ${ }^{34,35}$

Worth to note that from previous study, quantitative measurement of visceral adipose tissue using Bioelectric Impedance Analysis as applied in this study, eventhough in this research visceral fat measurement has not been using gold standard examination but the AUC yielded $71.8 \%$ sensitivity and $93.8 \%$ specificity. $3,19,21,33,36$ 


\section{CONCLUSION}

We conclude that RBP-4 level was higher in insulin resistance group among PCOS patients with normal BMI even though it can not be used as a marker for visceral adipose tissue. Visceral adipose tissue can be used as a marker for insulin resistance in lean PCOS with AUC 0.801 with $66.7 \%$ sensitivity and $80 \%$ specificity. The optimum cut off point was 5.5 based on this study. Waist circumference examination can be used as a predictor in determining insulin resistance in lean PCOS patient and do not need further sophisticated examination. Further investigation is needed due to variations of protein present which will be potential to be assessed as insulin resistance marker in PCOS patients.

\section{REFERENCES}

1. Teede H, Deeks A, Moran L. Polycystic ovary syndrome: a complex condition with psychological, reproductive and metabolic manifestations that impacts on health across the lifespan. BMC Med. 2010;8(1):41.

2. Guzick DS. Polycystic ovary syndrome. Obstet Gynecol. 2004;103(1):181-93.

3. Hutchison SK, Harrison C, Stepto N, Meyer C, Teede HJ. Retinol-binding protein 4 and insulin resistance in polycystic ovary syndrome. Diabet Care. 2008;31(7):1427-32.

4. Rojas J, Chavez M, Olivar L, Rojas M, Morillo J, Mejias J, et al. Polycystic Ovary Syndrome, Insulin Resistance, and Obesity: Navigating the Pathophysiologic Labyrinth. Int J Reprod Med. 2014;2014(1):1-17.

5. Gonzalez F. Inflammation in Polycystic Ovary Syndrome: underpinning of insulin resistance and ovarian dysfunction. Steril. 2012;77(4):300-5.

6. Tremellen K, Pearce K. Dysbiosis of Gut Microbiota (DOGMA) - A novel theory for the development of Polycystic Ovarian Syndrome. Med Hypotheses. 2012;79(1):104-12.

7. Chan T-F, Tsai Y-C, Chiu P-R, Chen Y-L, Lee C-H, Tsai $\mathrm{E}-\mathrm{M}$. Serum retinol-binding protein 4 levels in nonobese women with polycystic ovary syndrome. Fertil Steril. 2010;93(3):869-73.

8. Carmina E, Bucchieri S, Esposito A, et al. Abdominal fat quantity and distribution in women with polycystic ovary syndrome and extent of its relation to insulin resistance. J Clin Endocrinol Metabol. 2007;92(7):25005.

9. Wajchenberg BL. Subcutaneous and visceral adipose tissue: their relation to the metabolic syndrome. Endocrine reviews. 2000;21(6):697-738.

10. Hammarstedt A, Graham TE, Kahn BB. Adipose tissue dysregulation and reduced insulin sensitivity in nonobese individuals with enlarged abdominal adipose calls. Diabetol Metabol Syndrome J. 2012; 4:42

11. Marino JS, Iler J, Dowling AR, Chua S, Bruning JC, Coppari $R$, et al. Adipocyte dysfunction in a mouse model of polycystic ovary syndrome (PCOS): evidence of adipocyte hypertrophy and tissue-specific inflammation. PLoS One. 2012;7(10):e48643.
12. Preis SR, Massaro JM, Robins SJ, et al. Abdominal subcutaneous and visceral adipose tissue and insulin resistance in the Framingham heart study. Obes. 2010;18(11):2191-8.

13. Maury E, Brichard S. Adipokine dysregulation, adipose tissue inflammation and metabolic syndrome. Mol Cell Endocrinol. 2010;314(1):1-16.

14. Lee JW, Im JA, Lee $H R$, Shim JY, Youn BS, Lee DC. Visceral Adiposity Is Associated with Serum Retinol Binding Protein-4 Levels in Healthy Women. Obes. 2007:15(9):2225-32.

15. Möhlig M, Weickert MO, Ghadamgahi E, et al. Retinolbinding protein 4 is associated with insulin resistance, but appears unsuited for metabolic screening in women with polycystic ovary syndrome. Eur J Endocrinol. 2008;158(4):517-23.

16. Polak K, Czyzyk A, Simoncini T, Meczekalski B. New markers of insulin resistance in polycystiv ovary syndrome. J Endocrinol Invest. 2017; 40:1-8.

17. Yang Q, Graham TE, Mody N, et al. Serum retinol binding protein 4 contributes to insulin resistance in obesity and type 2 diabetes. Nature. 2005;436(7049):356-62.

18. Gavi S, Stuart LM, Kelly $P$, et al. Retinol-binding protein 4 is associated with insulin resistance and body fat distribution in nonobese subjects without type 2 diabetes. J Clin Endocrinol Metabol. 2007;92(5):188690.

19. Graham $T E$, Yang $Q$, Blüher $M$, et al. Retinol-binding protein 4 and insulin resistance in lean, obese, and diabetic subjects. New Eng J Med. 2006;354(24):255263.

20. Sopher AB, Gerken AT, Blanner WS, etal. Metabolic manifestations of polycystic ovary syndrome in nonobese adolescents: retinol-binding protein 4 and ectopic fat deposition. Fertil Steril. 2012;97(4):1009-15.

21. Hahn S, Backhaus M, Broecker-Preuss M, et al. Retinolbinding protein 4 levels are elevated in polycystic ovary syndrome women with obesity and impaired glucose metabolism. Eur J Endocrinol. 2007;157(2):201-7.

22. Lee J-W, Lee H-R, Shim J-Y, Im J-A, Lee D-C. Abdominal visceral fat reduction is associated with favorable changes of serum retinol binding protein-4 in nondiabetic subjects. Endocrinol J. 2008;55(5):811-8.

23. Jia $W, W u H, B a o ~ Y$, et al. Association of serum retinolbinding protein 4 and visceral adiposity in Chinese subjects with and without type 2 diabetes. J Clin Endocrinol Metabol. 2007;92(8):3224-9.

24. Barber TM, Hazell M, Christodoulides $C$, et al. Serum levels of retinol-binding protein 4 and adiponectin in women with polycystic ovary syndrome: associations with visceral fat but no evidence for fat massindependent effects on pathogenesis in this condition. J Clin Endocrinol Metabol. 2008;93(7):2859-65.

25. Niu Z, Lin N, Gu R et al. Association between insulin resistance, free fatty acids, and oocyte quality in polycystic ovary syndrome during In Vitro fertilization. J Clin Endocrinol Metabol. 2014; 99(11): 2269-76.

26. Matthews DR, Hosker JR, Rudenski AS, et al. Homeostasis model assessment: insulin resistance and fl-cell function from fasting plasma glucose and insulin consentrations in man. Diabet. 1985; 28: 412-9.

27. Budi Wiweko RM. Profil Resistensi Insulin pada Pasien Sindrom Ovarium Polikistik (SOPK) di RS Dr. Cipto Mangunkusumo Jakarta. Maj Obstet Ginekol Indones. 2008; 32(2): 93-8. 
28. Fatati I. Cut off point kadar visfatin per luas bidang lingkar pinggang sebagai penanda lemak viseral abdomen untuk menilai risiko resistensi insulin pada penderita sindrom ovarium polikistik. Departmen Obstetri dan Ginekologi. Jakarta: Universitas Indonesia 2010.

29. Mahde A, Shaker M, Al-Mashhadani Z. Study of omentin1 and other adipokines and hormones in PCOS patients. Oman Med J. 2009;24(2):108.

30. Iuorno MJ. Role of hyperinsulinemic insulin resistance in polycystic ovary syndrome. In: Gabor T Kovacs RN, (ed.) Polycystic Ovary Syndrome. 1st Edition ed. Cambridge: Cambridge University Press 2007; 204-14.

31. Meirow D. Insulin resistance and obesity. In: Hamburg R, (ed.) Polycystic Ovary Syndrome. London: Martin Dunitz Ltd. 2001: 93-106.

32. Promintzer $M$, Krebs $M$, Todoric J, Luger $A$, Bischof MG, Nowotny P, Wagner O, Ester- bauer $\mathrm{H}$, Anderwald C. Insulin resistance is unrelated to circulating retinol binding pro- tein and protein $\mathrm{C}$ inhibitor. J Clin Endocrinol Metabol. 2007;92:4306-12.
33. Weiping $L$, Qingfeng C, Shikun $M$, Xiurong L, Hua Q, Xiaoshu B, Suhua Z, Qifu L. Elevated serum RBP4 is associated with insulin resistance in women with polycystic ovary syndrome. Endocrinol. 2006; 30(3):2837.

34. Inadera $\mathrm{H}$. The usefulness of circulating adipokine levels for the assessment of obesity-related health problems. Int J Med Sci. 2008;5(5):248-62.

35. Esteve E, Ricart W, Fernandez-Real JM. Adipocytokines and insulin resistance: the possible role of lipocalin-2, retinol binding protein-4, and adiponectin. Diabet Care. 2009;32(2):362-7.

36. Fernandes RA, Rosa CS, Buonani C, Oliveira ARd, Freitas Júnior IF. The use of bioelectrical impedance to detect excess visceral and subcutaneous fat. J Pediatria. 2007;83(6):529-34. 